\title{
Complex mating behavior in Adelosgryllus rubricephalus (Orthoptera, Phalangopsidae, Grylloidea)
}

\author{
Edison Zefa ${ }^{1,2}$, Luciano de P. Martins² \& Neucir Szinwelski ${ }^{3}$
}

1. Departamento de Zoologia e Genética, Instituto de Biologia, Universidade Federal de Pelotas (UFPel), 96010-900 Capão do Leão, RS, Brazil. (edzefa@gmail.com)

2. Departamento de Biologia, Instituto de Biociências, Universidade Estadual Paulista (UNESP), Avenida 24-A, 1515, Caixa Postal 199, 13506-900 Rio Claro, SP, Brazil. (lucianodpm@gmail.com)

3. Depto. de Biologia Animal, Universidade Federal de Viçosa (UFV), Avenida Peter Henry Rolfs, s/n, Campus Universitário, 36570000 Viçosa, MG, Brazil. (neucirufv@gmail.com)

\begin{abstract}
We describe the mating behavior of Adelosgryllus rubricephalus Mesa \& Zefa, 2004. In trials carried out in laboratory we verified the following mating sequence: (1) sexual recognition by antennation; (2) courtship with male turning his abdomen towards the female, performing mediolateral antennae vibration, jerking its body antero-posteriorly and stridulating intermittently, while receptive female drums on the male's abdomen tip, cerci and hind-tibia with her palpi or foretarsi; the male then stops and stays motionless for some seconds, extrudes the spermatophore and both restart the behavioral sequence described above; (3) copulation: male underneath female; with his tegmina inclined forward, and joins his genitalia to the female's to promote sperm transference ; the female steps off the male, occurring a brief end-to-end position; (4) postcopulation: without guarding behavior; male retains the spermatophore and eats it. We quantified elapsed time of each behavioral sequence and discussed its implications in the observed mating behavior.
\end{abstract}

KEYWORDS. Insecta, Phalangopsidae, crickets, courtship, copulation.

RESUMO. Comportamento Complexo de Acasalamento em Adelosgryllus rubricephalus (Orthoptera, Gryllidae). Descrevemos o comportamento reprodutivo de Adelosgryllus rubricephalus Mesa \& Zefa, 2004. Em observações realizadas em laboratório verificamos a seguinte seqüência no comportamento de acasalamento: (1) reconhecimento sexual por antenação; (2) corte, em que o macho volta seu abdômen em direção à fêmea, vibra as antenas médio-lateralmente, treme o corpo ântero-posteriormente e estridula intermitentemente, enquanto a fêmea receptiva toca a ponta do abdômen, os cercos e os fêmures posteriores do macho, com seus palpos ou tarsos anteriores: o macho então fica imóvel por alguns segundos, expõe o espermatóforo e ambos retomam a seqüência comportamental descrita acima; (3) cópula: o macho coloca-se sob a fêmea, com suas tégminas inclinadas para frente, anexa sua genitália à dela e promove a transferência do esperma; a fêmea desce de cima do macho e ocorre brevemente a posição "end-to-end" durante a separação do casal; (4) pós-cópula: não há comportamento de guarda; o macho retém o espermatóforo e o ingere. Quantificamos o intervalo de tempo das principais etapas do acasalamento e discutimos suas possíveis implicações no comportamento observado.

PALAVRAS-CHAVE. Insecta, Phalangopsidae, grilos, corte, cópula.

The crickets' reproductive behavior includes a set of events beginning with males attracting females by means of acoustic signals (ALEXANDER, 1962,1967) or by emission of specific pheromone (Brown, 1999; Prado, 2005). Sexual recognition occurs through antennation (Loher \& Dambach, 1989; Tregenza \& Wedell, 1997), triggering the male's courtship rituals that simultaneously comprise the emission of acoustic signals, antennae vibrations, maxillary palpi touches and body vibrations (Alexander, 1967; Bell, 1980). Copulation may be preceded or followed by delivering of male's nuptial gift, such as glandular secretion (HANCOCK, 1905; WALKER \& GURNEY, 1967), hemolymph (PRADO, 2005), spermatophore (VAHED, 1998; Shaw \& KhINe, 2004) or spermatophylax (SAKALUK, 1984). During copulation there may or may not occur spermatophore transference, which is correlated with male's strategies to keep female in copulating position, as well as with male's postcopulation behavior.

Reproductive behavior in crickets has been subject of many studies, but few on Phalangopsidae, which is one of the most important cricket families, both in terms of taxon number and ecological diversity (DESUTTERGRANDCOLAS, 1995). Up to now, only five Phalangolpsidae species have been analyzed regarding reproductive behavior: Nemoricantor mayus (Hubbell, 1938) (Alexander \& OtTe, 1967; Boake \& Capranica, 1982; BOAKe, 1984), Phaeophilacris spectrum Saussure, 1878
(Dambach \& Lichtenstein, 1978), Vanzoliniella sambophila Mello \& Reis, 1994 (Mello \& ReIs, 1994), Ecuazarida recondita Nischk \& Otte, 2000 (NISCHK \& Oтте, 2000) and Eidmanacris corumbatai Garcia, 1998 (PRADO, 2005).

Adelosgryllus rubricephalus Mesa \& Zefa, 2004 has a wide geographical distribution, extending from northeastern to southern Brazil. They occur in diverse habitats, from "cerradão" forest vegetation, to urban areas, always close to the ground, on leaf litter, sometimes hiding within or under rotten wood, or walking on the foliage during day time (Mesa \& Zefa, 2004). The aim of this paper was to describe the mating behavior in $A$. rubricephalus.

\section{MATERIAL AND METHODS}

Nymphs of A. rubricephalus were collected at Horto Florestal Irmão Teodoro Luiz, city of Capão do

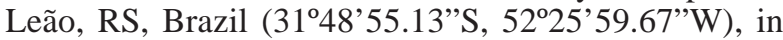
October and November 2004. Specimens were reared to adulthood at $25 \pm 2^{\circ} \mathrm{C}$ with an $12 \mathrm{~h}: 12 \mathrm{~h}$ day:night cycle, in a terrarium $(30 \times 35 \times 69 \mathrm{~cm})$ with soil and leaf litter substratum, on a diet of fish food and water in cottonplugged vials.

Trials were carried out in two phases, one to trace the main stages of the reproductive behavior and another 
to measure the time duration of each stage. In the first phase we accomplished 25 meetings, with adult males and females previously kept separated from each other for five days. During this period they were individually maintained in glass vials $(10 \mathrm{~cm}$ diameter and $15 \mathrm{~cm}$ height with sand substrate, water and food. These vials were used as arena and observations were carried out under dim light, at room temperature.

In the second phase we accomplished 34 meetings, in order to register the elapsed time from antennation to the spermatophore extrusion, from spermatophore extrusion to copulation beginning, duration of copulation, and elapsed time from antennation to pair splitting apart.

The main stages of mating behavior were photographed with digital camera Fuji 6.0 MP.

\section{RESULTS}

The male A. rubricephalus is more active than the female, when both are placed together. The male walks along the arena, palpating and antennating substrate, reaching the female and antennating any part of her body. After antennation, male starts different kinds of intermittent behaviors: mediolateral antennae vibration, anteroposterior body jerking and stridulation (Fig. 1, arrow), turning his abdomen towards the female. Each of these movements generally occurs individually.

During male courting, receptive female approaches and drums on the male's abdomen tip, cerci and hind tibia, with her foretarsi or palpi (Fig. 1, arrow). After that,
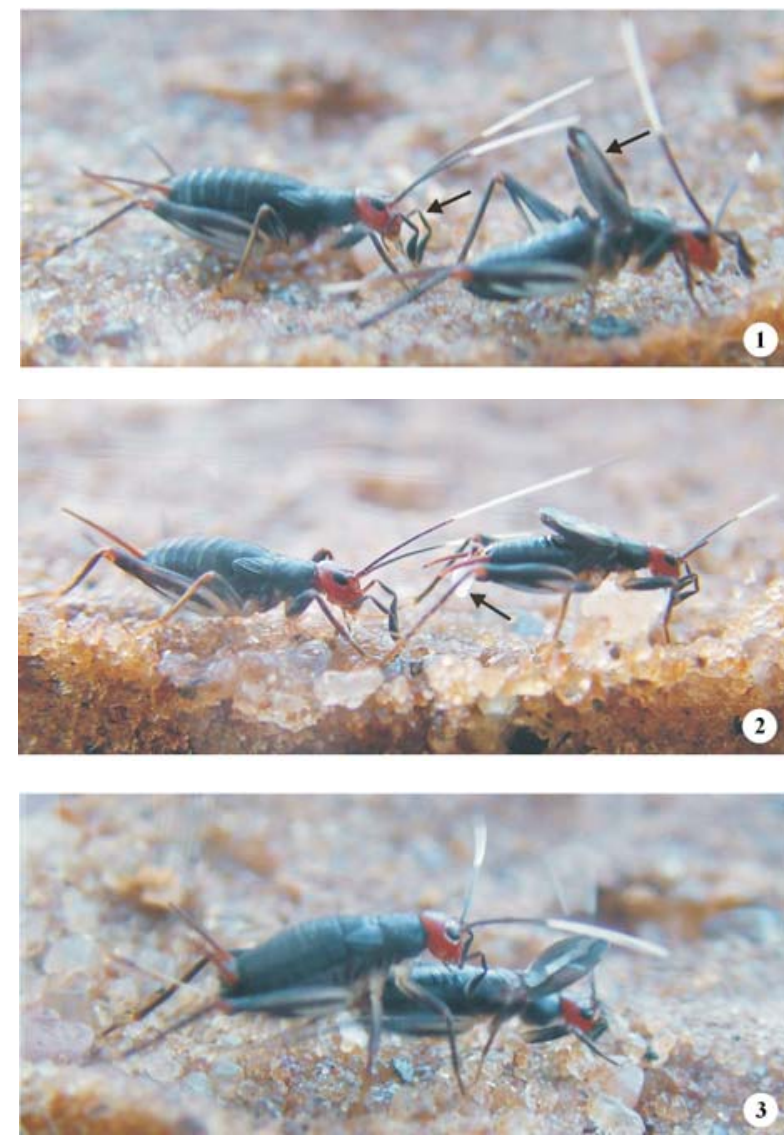

Figs. 1-6. Mating behavior of Adelosgryllus rubricephalus Mesa \& Zefa, 2004. 1, courtship position; male stridulating with raised tegmens (arrow); female behind male, arrow=palpi; 2, courtship position, arrow=spermatophore; 3 , male walking back underneath the female; 4 , female above

position, arrow=male's tegmens inclined forward from vertical; 5, end-to-end position; 6, male eating the spermatophore (arrow).

male extrudes a soft, sticky and whitish spermatophore (Fig. 2, arrow), which becomes gradually translucent and rigid. The spermatophore was never extruded before female's drumming behavior.

After spematophore extrusion, male continues vibrating its antennae, jerking its body and stridulating intermittently, while female intensifies her drumming. During the courtship, male and female body movements suggest female's attempt to remove the spermatophore, while male tries to hinder it. From the 59 meetings analyzed here, only on one occasion did the female remove the spermatophore and ate it immediately, although the mating sequence was continued normally, and after pair separation, male tried to get the absent spermatophore.

After courtship behavior, male walks back underneath female (Fig. 3), performing a female-above position, using his genitalia to transfer spermatophore (Fig. 4). While in copulating position, male holds his tegmina inclined forward (Fig. 4, arrow), and female's head is held behind male forewings. Both male's and female's antennae are held motionless forward (Fig. 4). Eventually the male lifts his abdomen tip thrusting against the female's abdomen. After female steps off male, both perform a brief end-to-end position (Fig. 5). On some occasions, female drags for some centimeters before the definitive separation.

In postcopulation, there is no guarding behavior; male retains the spermatophore, bends his body to picks it up and eats it immediately (Fig. 6, arrow). A few minutes latter, male starts courtship behavior again.
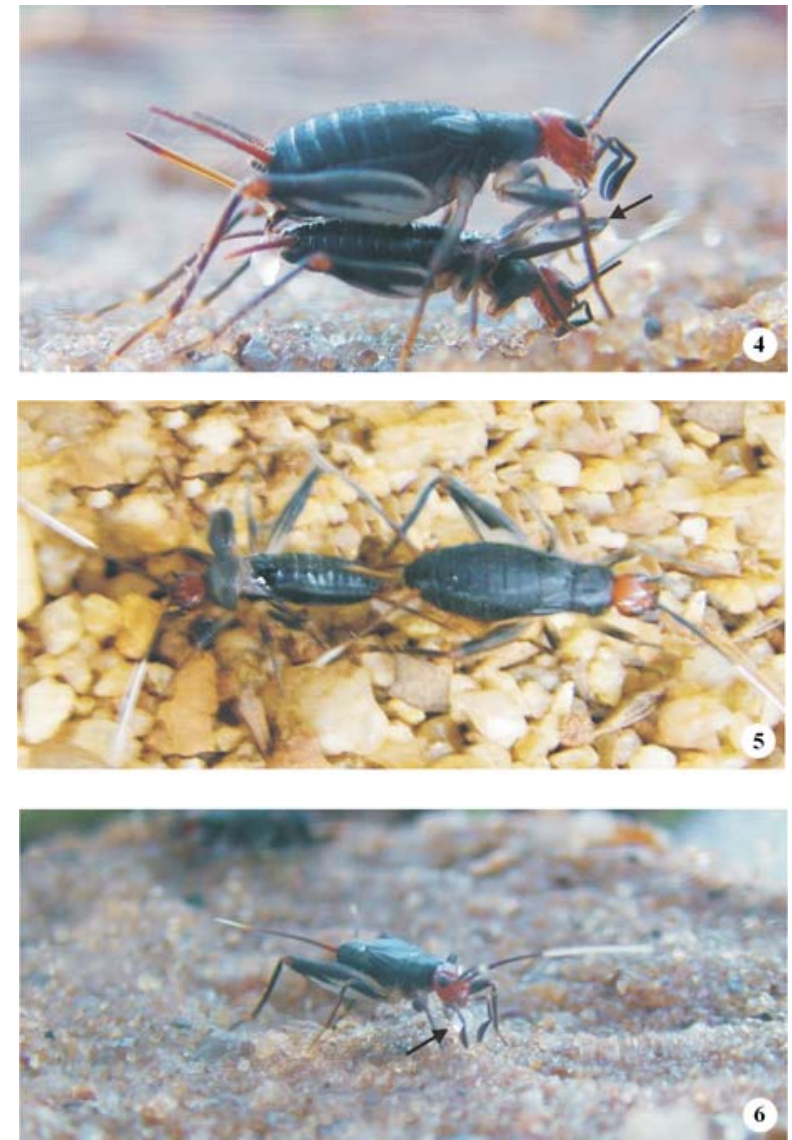
The elapsed time from antennation to spermatophore extrusion is $24.5 \pm 12.4 \mathrm{~min}$; the elapsed time from spermatophore extrusion to copulation is $21.1 \pm 4.9 \mathrm{~min}$; copulation duration is $6.7 \pm 3.9 \mathrm{~min}$ and the elapsed time from antennation to pair splitting apart is $52.5 \pm 12.1 \mathrm{~min}$ (Tab. I).

\section{DISCUSSION}

Crickets' intraspecific communication is multimodal, including chemical, mechanical and acoustical stimulation (Alexander, 1962; Bell, 1980). Males of A. rubricephalus always begin courtship behavior after touch of antennae. The antennae possess mechanoreceptors and chemoreceptors that recognize specific pheromones indicating the sexual condition for the mating (Balakrishnan \& Pollack, 1997; Tregenza \& Wedell, 1997).

Table I. Time duration of each phase of the mating behavior of Adelosgryllus rubricephalus. Mesa \& Zefa, 2004. N, pairs analyzed; A, elapsed time since the antennation until the spermatophore extrusion; B, elapsed time since the spermatophore extrusion until the copulation beginning; C, copulation elapsed time; D, elapsed time since the antennation until the pair separation; E, temperature at the moment of observation; $\overline{\mathrm{x}}$, mean \pm standard deviation. Time in minutes (* female removed the spermatophore and ate it).

\begin{tabular}{lccccc}
\hline $\mathrm{N}$ & $\mathrm{A}$ & $\mathrm{B}$ & $\mathrm{C}$ & $\mathrm{D}$ & $\mathrm{E}$ \\
\hline 01 & 06 & 14 & 08 & 28 & $20^{\circ} \mathrm{C}$ \\
02 & 09 & 21 & 07 & 37 & $20^{\circ} \mathrm{C}$ \\
$03^{*}$ & 41 & 13 & 06 & 60 & $20^{\circ} \mathrm{C}$ \\
04 & 10 & 21 & 01 & 32 & $20^{\circ} \mathrm{C}$ \\
05 & 47 & 20 & 02 & 69 & $17^{\circ} \mathrm{C}$ \\
06 & 14 & 22 & 05 & 41 & $17^{\circ} \mathrm{C}$ \\
07 & 19 & 22 & 08 & 49 & $17^{\circ} \mathrm{C}$ \\
08 & 32 & 21 & 13 & 66 & $17^{\circ} \mathrm{C}$ \\
09 & 36 & 19 & 12 & 67 & $17^{\circ} \mathrm{C}$ \\
10 & 11 & 22 & 06 & 39 & $17^{\circ} \mathrm{C}$ \\
11 & 28 & 12 & 05 & 45 & $17^{\circ} \mathrm{C}$ \\
12 & 17 & 31 & 05 & 62 & $13^{\circ} \mathrm{C}$ \\
13 & 08 & 28 & 09 & 45 & $17^{\circ} \mathrm{C}$ \\
14 & 19 & 25 & 06 & 50 & $17^{\circ} \mathrm{C}$ \\
15 & 29 & 32 & 07 & 68 & $17^{\circ} \mathrm{C}$ \\
16 & 15 & 25 & 04 & 44 & $17^{\circ} \mathrm{C}$ \\
17 & 17 & 28 & 08 & 53 & $17^{\circ} \mathrm{C}$ \\
18 & 13 & 28 & 04 & 45 & $17^{\circ} \mathrm{C}$ \\
19 & 13 & 20 & 14 & 47 & $18.5^{\circ} \mathrm{C}$ \\
20 & 15 & 20 & 14 & 49 & $18.5^{\circ} \mathrm{C}$ \\
21 & 28 & 20 & 05 & 53 & $18.5^{\circ} \mathrm{C}$ \\
22 & 18 & 29 & 02 & 49 & $18.5^{\circ} \mathrm{C}$ \\
23 & 46 & 18 & 05 & 69 & $18.5^{\circ} \mathrm{C}$ \\
24 & 21 & 23 & 09 & 53 & $18.5^{\circ} \mathrm{C}$ \\
25 & 15 & 22 & 04 & 41 & $18.5^{\circ} \mathrm{C}$ \\
26 & 30 & 18 & 05 & 51 & $21.5^{\circ} \mathrm{C}$ \\
27 & 30 & 16 & 14 & 60 & $21.5^{\circ} \mathrm{C}$ \\
28 & 33 & 18 & 01 & 52 & $21.5^{\circ} \mathrm{C}$ \\
29 & 18 & 16 & 05 & 39 & $21.5^{\circ} \mathrm{C}$ \\
30 & 27 & 17 & 02 & 46 & $21.5^{\circ} \mathrm{C}$ \\
31 & 40 & 18 & 04 & 62 & $18.5^{\circ} \mathrm{C}$ \\
32 & 46 & 19 & 10 & 75 & $18.5^{\circ} \mathrm{C}$ \\
33 & 46 & 19 & 05 & 70 & $18.5^{\circ} \mathrm{C}$ \\
34 & 37 & 20 & 14 & 71 & $18.5^{\circ} \mathrm{C}$ \\
\hline$\overline{\mathrm{x}}$ & $24.5 \pm 12.4$ & $21.1 \pm 4.9$ & $6.7 \pm 3.9$ & $52.5 \pm 12.1$ & \\
\hline & & & & &
\end{tabular}

The mediolateral antennae vibration performed by male A. rubricephalus never touches the female. These movements are common in crickets' courtship behavior and there are no clues for their signaling function (Alexander \& Otte, 1967; Love \& Walker, 1979; Evans, 1998).

Courtship body vibrations were also verified elsewhere (AlexANDER \& OTTE, 1967; Love \& WALKer, 1979; DAMBACH \& BeCK, 1990; Brown, 1999), but there are few studies describing the details of this behavior. In Oecanthus nigricornis Walker, 1869, BELL (1980) observed four discrete types of male body vibration in mating. The vibrational-energy provokes vibration of movable substrate (BELL, 1980), which is perceived by crickets as nervous impulses through the subgenual organs (Alexander \& Brown, 1963). According to GabBut (1994), the irregular jerking of the body of Nemobius sylvestris (Bosc, 1792) is probably the primary stimulus for females in the pre-copulatory phase. In $A$. rubricephalus, the anteroposterior jerking of the body occurs as in the phalangopsid crickets Nemoricantor mayus (AlexANDer \& OTte, 1967) and Endecous itatibensis Rehn, 1918 (E. Zefa, pers. obs.), and its function need to be experimentally tested.

During courtship, A. rubricephalus shows the spermatophore, as occurs with Hapithus agitator Uhler, 1864, N. mayus, Phyllopalpus pulchellus Uhler, 1864 (AlexAnder \& OTte, 1967) and Trigonidium (Balamara) gidya (Otte \& Alexander, 1983) (Evans, 1998). This behavior must be related to a sexual attribute that females may use as information on the genetic qualities of the male (see BRown, 1999), or the large spermatophore probably is a male's strategy to stimulate females to copulate, allured by the nutritional value of the spematophore. Under this perspective, EvANS (1998) verified that females of the Bobilla victoriae Otte \& Alexander, 1983, like in A. rubricephalus, had tried to remove male's spermatophore with success in few occasions. The female of $B$. victoriae also ate the spermatophore, but differently from A. rubricephalus, the mating sequence was interrupted.

The nutrients present in the spermatophore eaten by $A$. rubricephalus males, are supposedly used for the production of another one, allowing subsequent successful mating. Preliminary tests taking off spermatophores in two subsequent copulations of the same male showed a drastic reduction in the size of the newly produced spermatophore.

The elapsed time spent from antennation to spermatophore extrusion is probably used to produce the new spermatophore. The elapsed time from spermatophore extrusion to copulation is probably necessary to solidify the newly produced spermatophore, allowing subsequent sperm transfer. The latter hypothesis was partially tested analyzing spermatophores at different stages after extrusion, showing that its composition modifies gradually from soft, sticky and whitish to translucent and rigid.

Male's raised tegmina position during copulation may be explained by two hypotheses: this position may display the openings of metanotal glands, that produce secretions (nuptial gifts), as occurs, e.g., in E. corumbatai 
(PRADO, 2005); on the other hand, it may be due to stridulation while copulating, as occurs in the Phalangopsidae E. itatibensis (E. Zefa, pers. obs.). According to our observations, there are no gland openings on the metanotum of $A$. rubricephalus, rejecting the first hypothesis. The second hypothesis cannot be rejected, based on the presence of a functional stridulatory file that produces songs during courtship.

The duration of copulation is highly variable among Grylloidea (LOHER \& DAMBACH, 1989). According to AleXANDER \& OTTE (1967), long copulation is prevalent in groups with metanotal secretions, without spermatophore transfer; short copulation generally occurs in groups without metanotal secretions, and with spermatophore transfer. The Phalangopsidae $N$. mayus (AleXANDer \& OTte, 1967), E. recondita (NischK \& OTte, 2000) and E. corumbatai (PRADO, 2005) are in accordance to the former situation, but in A. rubricephalus, there are no spermatophore transfer, its copulation is also long, although there are no methanotal glands.

The sequence of mating behavior in $A$. rubricephalus is similar to most of the true crickets (Gryllidae): including sexual recognition through antennation, courtship with jerking of the body, movements of antennae, stridulation and copulation in female-above position. Although the number of Phalangopsidae species studied is reduced, a diverse array of mating behaviors were observed, e.g., wing flicking in P. spectrum (HeIzel \& DAmBACH, 1987), substrate drumming in V. sambophila (MeLlo \& REIS, 1994), aggressive warning courtship song in $N$. mayus (BOAKE \& CAPRANICA, 1982), and so one. Here we still present another set of mating behaviors, reinforcing that Phalangopsidae is a rich material for studying mating behavior.

Acknowledgements. We would like to thank Rogilene Ap. Prado (UNESP) for the suggestions. Marco Antonio Afonso Coimbra (UFPel) for helping help in the field work. Cristiane Meleo for technical support. Prof. Dr. Paulo Bretanha Ribeiro (UFPel) for the climate room to rear the crickets and Cybel Burgess and Jonathan Burgess for the English review.

\section{REFERENCES}

Alexander, R.D. 1962. Evolutionary change in cricket acoustical communication. Evolution 16(4):443-467.

1964. The evolution of mating behavior in arthropods. In: Highnam, K. C. ed. Insect Reproduction Symposium N. 2. Royal Entomological Society. London, p.78-94.

1967. Acoustical communication in arthropods. Annual Review of Entomology 12:495-526.

Alexander, R. D. \& Brown, W. L. 1963. Mating behavior and the origin of insect wings. Occasional Papers of the Museum of Zoology of the University of Michigan 628:1-19.

Alexander, R. D. \& OTte, D. 1967. The evolution of genitalia and mating behavior in crickets (Gryllidae) and other Orthoptera. Miscellaneous Publications Museum of Zoology, University of Michigan 133:1-62.

Balakrishnan, R. \& Pollack, G. S. 1997. The role of antennal sensory cues in female responses to courting males in the cricket Teleogryllus oceanicus. The Journal of Experimental Biology 200:511-522.
Bell, P. D. 1980. Multimodal communication by the blackhorned tree cricket, Oecanthus nigricornis (Walker) (Orthoptera: Gryllidae). Canadian Journal of Zoology 58: $1861-1868$

BoAKe, C. R. B. 1984. Natural history and acoustic behavior of a gregarious cricket. Behaviour 89(3-4):241-250.

BoAke, C. R. B. \& CApranica, R. R. T. I. 1982. Aggressive signal in 'courtship' chirps of a gregarious cricket. Science 218(4575):580-582.

Brown, W. D. 1999. Mate choice in tree crickets and their kin. Annual Review of Entomology 44:371-396.

Dambach, M. \& Lichtenstein, L. 1978. Zur Ethologie der afrikanischen Grille Phaeophilacris spectrum Saussure. Zeitschrift für Tierpsychologie 46:14-29.

DAмвасн, M. \& BECK, U. 1990. Mating in the scaly cricket Cycloptiloides canariensis (Orthoptera: Gryllidae: Mogoplistinae). Ethology 85:289-301

Desutter-Grandcolas, L. 1995. Toward the knowledge of the evolutionary biology of phalangopsid crickets (Orthoptera: Grylloidea: Phalangopsidae): data, questions and evolutionary scenarios. Journal of Orthoptera Research 4:163-175.

Evans, A. R. 1998. Mating Systems and reproductive strategies in three Australian gryllid crickets: Bobilla victoriae Otte, Balamara gidya Otte and Teleogryllus commodus (Walker) (Orthoptera: Gryllidae: Nemobiinae: Trigonidiinae; Gryllinae). Ethology 78:21-52.

GabBut, P.D. 1994. Notes on the mating behaviour of Nemobius sylvestris (Bosc) (Orth., Gryllidae). Animal Behaviour 2(3):84-88.

Hancock, J. J. 1905. The habits of the striped meadow cricket (Oecanthus fasciatus Fitch). American Naturalist 39:1-11.

Heizel, H-G. \& DAmBACH, M. 1987. Travelling air vortex rings as potential communication signals in a cricket. Journal of Comparative Physiology. A, Sensory, Neural, and Behavioral Physiology 160:79-88.

LOHER, W. \& DAMBACH, M. 1989. Reproductive behavior. In: Huber, F.; Moore, T. E. \& Loher, W. eds. Cricket Behavior and Neurobiology. Ithaca, New York, Cornell University. p. $43-82$.

Love, E. R. \& Walker, T. J. 1979. Systematics and acoustic behavior of scaly crickets (Orthoptera: Gryllidae: Mogoplistinae) of eastern United States. Transactions of the American Entomological Society 105:1-66.

Mello, F. A. G. \& Reis, J. C. 1994. Substrate drumming and wing stridulation performed during courtship by a new Brazilian cricket (Orthoptera: Grylloidea: Phalangopsidae). Journal of Orthoptera Research 2:21-24.

MesA, A. \& ZEFA, E. 2004. Adelosgryllus rubricephalus: a new genus and species of cricket (Orthoptera: Phalangopsidae). Neotropical Entomology 33(3):327-332.

NischK, F. \& OtтE, D. 2000. Bioacoustic, ecology and systematic of Ecuadorian rainforest crickets (Orthoptera: Gryllidae: Phalangopsinae), with a description of four new genera and ten new species. Journal of Orthoptera Research 9:229-254.

PRADO, R. 2005. Reproductive behavior of E. corumbatai Garcia (Orthoptera: Phalangopsidae). Neotropical Entomology 35(4): 452-457

SAKALUK, S. K. 1984. Male crickets feed females to ensure complete sperm transfer. Science 233:609-610.

Shaw, K.L. \& Khine, A. H. 2004. Courtship behavior in the Hawaiian cricket Laupala cerasina: males provide spermless spermatophores as nuptial gifts. Ethology 110:81-95.

Tregenza, T. \& Wedell, N. 1997. Definitive evidence for cuticular pheromones in a cricket. Animal Behaviour 54:979-984.

VAHED, K. 1998. The function of nuptial feeding in insects: a review of empirical studies. Biological Reviews 73:43-78.

Walker, T. J. \& GuRney, A. B. 1967. The metanotal gland as a taxonomic character in Oecanthus of the United States (Orthoptera: Gryllidae). Proceedings of the Entomological Society of Washington 69:157-161.

Recebido em abril de 2007. Aceito em dezembro de 2007. ISSN 0073-4721

Artigo disponível em: www.scielo.br/isz 